MAŁGORZATA CHOJARA-SOBIECKA

Okręgowa Izba Radców Prawnych w Krakowie

KS. PIOTR KROCZEK

Wydział Nauk Społecznych

Uniwersytetu Papieskiego Jana Pawła II w Krakowie

\title{
O MOŻLIWOŚCI WPROWADZENIA DO POLSKIEGO SYSTEMU PRAWNEGO OCHRONY (KANONICZNEJ) TAJEMNICY DUSZPASTERSKIEJ
}

Treść: - 1. Ochrona informacji w obowiązującym stanie prawnym. - 2. Brak ochrony tajemnicy duszpasterskiej. - 3. Aksjologiczne podstawy ochrony tajemnicy duszpasterskiej. - 4. Relacja państwa i Kościoła. - 5. Drogi wprowadzenia ochrony tajemnicy duszpasterskiej. - 6. Dyskusja nad drogami wprowadzenia ochrony tajemnicy duszpasterskiej. - 7. Regulacje kanoniczne dotyczące tajemnicy duszpasterskiej. - 8. Zakres podmiotowy i przedmiotowy ochrony tajemnicy duszpasterskiej. - 9. Zakaz dowodowy w prawie polskim. - 10. Kwestie redakcyjno-legislacyjne. - 11. Korzyści z ochrony tajemnicy duszpasterskiej.

\section{Ochrona informacji w obowiązującym stanie prawnym}

Zarówno w prawie polskim jak i w prawie kanonicznym (w tym artykule rozumianym jako prawo Kościoła rzymskokatolickiego) występują regulacje zakazujące ujawniania pewnych informacji oraz korespondujące $\mathrm{z}$ nimi przepisy chroniące ten obowiązek lub ustanawiające sankcje za jego niedotrzymanie. Regulacje te dotyczą spraw własnych toczących się na forum wewnętrznym państwa czy Kościoła, ale także spraw obcych.

W tym drugim rodzaju spraw istnieje nieproporcjonalność wzajemnej ochrony pomiędzy państwem a wspomnianym Kościołem. 
Po pierwsze, gwarantowana w prawie polskim ochrona treści powierzonych podczas spowiedzi występuje wprawdzie na gruncie prawa cywilnego, administracyjnego i karnego ${ }^{1}$, jednak - jak słusznie podnosi się w literaturze przedmiotu - zakres tej ochrony nie odpowiada zakresowi przedmiotowemu i podmiotowemu tej tajemnicy określanych przez prawo kanoniczne ${ }^{2}$. W prawie polskim jest on węższy. Dodatkowo, po nowelizacji w 2016 r. ustawy o Policji kontrowersyjna jest moc obowiązywania tej ochrony w przypadku działań operacyjnych Policji ${ }^{4}$. Po drugie, dysproporcja ta polega na tym, że o ile prawo kanoniczne uznaje niemożność ujawniania określonych faktów w związku z zakazem wynikającym z prawa świeckiego (zob. kan. $1548 \$ 2$ pkt $1^{5}$ w zw. z kan. 22 ), o tyle odwrotna sytuacja - poza

${ }^{1}$ Art. 178 pkt 2 ustawy z dnia 6 czerwca 1997 r. Kodeks postępowania karnego (tekst jedn. Dz. U. z 2016 r. poz. 1749 z późn. zm.), dalej: k.p.k.; art. $261 \S 2$ ustawy $\mathrm{z}$ dnia 17 listopada 1964 r. Kodeks postępowania cywilnego (tekst jedn. Dz. U. z 2016 r. poz. 1822 z późn. zm.) - dalej jako k.p.c.; art. 82 pkt 3 ustawy z dnia 14 czerwca 1960 r. Kodeks postępowania administracyjnego (tekst jedn. Dz. U. z 2017 r. poz. 1257) - dalej jako k.p.a.

${ }^{2}$ Zob. np. M. Rusinek, Tajemnica zawodowa i jej ochrona w procesie karnym, Kraków 2007, s. 65; M. Toмкiewicz, “Tajemnica spowiedzi” i "tajemnica duszpasterska” w procesie karnym, Prokuratura i Prawo (2012) nr 2, s. 55; M. Wielec, Zakaz dowodowy tajemnicy spowiedzi w postępowaniu karnym, Warszawa 2012, s. 264-265; H. KNysiak-Molczy K, Komentarz do art. 82 k.p.a., w: Kodeks postępowania administracyjnego. Komentarz, red. H. Knysiak-Molczyk, Warszawa 2015, Lex, teza 9.

${ }^{3}$ Ustawa z dnia 15 stycznia 2016 r. o zmianie ustawy o Policji oraz niektórych innych ustaw (Dz.U. 2016 poz. 147).

${ }^{4}$ Zgodnie bowiem z art. 19 ust. 15f pkt 1 ustawy o Policji w przypadku, gdy materiały zgromadzone podczas stosowania kontroli operacyjnej zawierają informacje, o których mowa w art. 178 k.p.k. (tajemnica obrończa i spowiedzi), Komendant Główny Policji, Komendant CBŚP albo komendant wojewódzki Policji zarządza ich niezwłoczne, komisyjne i protokolarne zniszczenie. Wydaje się, że należałoby wprowadzić przede wszystkim uregulowania mające na celu uniknięcie powstawania takich nagrań w ogóle, a w przypadku ich powstania mimo prewencyjnych uregulowań wprowadzić kontrolę sądową nad ich zniszczeniem.

${ }^{5}$ Cytowane kanony pochodzą z Codex Iuris Canonici auctoritate Ioannis Pauli PP. II promulgatus, 25.01.1983, AAS 75 (1983) pars II, s. 1-301; tekst łacińsko-polski: 
informacjami, o których duchowny dowiedział się podczas spowiedzi, o czym była już mowa - nie ma miejsca w porządku państwowym. Należy bowiem zauważyć, że polska procedura karna, cywilna czy też administracyjna nie chronią tajemnicy, którą mają na mocy prawa kanonicznego obowiązek zachować: sędziowie, asystenci sędziego i pomocnicy trybunału diecezjalnego (kan. $1455 \$ 1$, kan. $1455 \$ 2$; kan. $1550 \$ 2$ pkt 1; kan. $1609 \$ 2$ ), zobowiązani przysięgą świadkowie, biegli, strony, ich adwokaci lub pełnomocnicy (kan. $1455 \$ 3$, kan. 1550 $\$ 2$ pkt 1), osoby tworzące kolegium lub zespołu osób, których zgody lub rady wymaga prawo kanoniczne dla podjęcia czynności przez przełożonego (kan. $127 \S$ 3), biskupi diecezjalni (kan. 269 pkt 1, kan. $377 \$ 2$ i $\$ 3$ ) czy też osoby piastujące stanowiska w kurii diecezjalnej (kan. 471 pkt 2) ${ }^{6}$.

\section{Brak ochrony tajemnicy duszpasterskiej}

W literaturze przedmiotu został zauważony i jest obecnie dyskutowany (także na forum Rady Prawnej Konferencji Episkopatu Polski) jeszcze jeden element nieproporcjonalności, o której mowa. Chodzi o brak ochrony (kanonicznej) tajemnicy duszpasterskiej w prawie polskim ${ }^{7}$.

Ten brak ma przede wszystkim charakter praktyczny. Zdarzają się sytuacje, w których wierny w zaufaniu przekazuje (wyłącznie) duchownemu (z racji funkcji pełnionej przez duchownego w Kościele)

Kodeks Prawa Kanonicznego, przekład zatwierdzony przez Konferencję Episkopatu Polski, Poznań 1984.

${ }^{6}$ Odnośnie tajemnicy adwokata kościelnego zob. M. ToмkiEwicz, Tajemnica adwokacka adwokata kościelnego w prawie polskim. Zakres ochrony i skutki jej naruszenia, Studia z Prawa Wyznaniowego 19 (2016), s. 195-216.

${ }^{7}$ Zob. B. RAкосzy, Tajemnica spowiedzi w polskim postępowaniu karnym, cywilnym i administracyjnym, Przegląd Sądowy (2003) nr 11-12, s. 132; M. TомкIEwICz, „Tajemnica spowiedzi” $i$,tajemnica duszpasterska” $w$ procesie karnym, Prokuratura i Prawo (2012) nr 2, s. 50-64; B. Pieron, Tajemnica zawodowa (duszpasterska) duchownego, Annales Canonici 12 (2016), s. 131-153; zob. także P. KroczeK, Kilka uwag do znowelizowanych Wytycznych KEP w kontekście zasad techniki legislacyjnej oraz znowelizowanego art. $240 \$ 1$ Kodeksu karnego, Annales Canonici 13(2017), s. 91-107. 
pewne treści np. w ramach tzw. kierownictwa duchowego. Rozmowa wiąże się z zaufaniem, którym osoba powierzająca pewne treści darzy duchownego. Taka jest też ratio legis (kanonicznej) tajemnicy duszpasterskiej. Prawo polskie nie respektuje poufności tych rozmów. Duchowny ma więc obowiązek wyjawienia ich treści w pewnych okolicznościach, np. gdyby został powołany na świadka i zapytany o daną kwestię ${ }^{8}$.

Istotną sprawą jest to, że zgodnie z art. 240 k.k. każdy (także duchowny) ma obowiązek (także jako niepytany) zawiadomienia o podejrzeniu przygotowania albo usiłowania lub dokonania (także w bardzo odległym czasie) różnych rodzajów czynów zabronionych (np. przestępstwo zgwałcenia, obcowanie z małoletnim poniżej lat 15). Niewypełnienie tego obowiązku jest zagrożone karą pozbawienia wolności do lat trzech. Oznacza to, że duchowny, który powziął w ramach wykonywania swoich obowiązków duszpasterskich (przykładowo odwiedzając parafian - kan. $851 \mathrm{nr} 2$ kan. $529 \$ 1$, czy w czasie rozmowy w kancelarii) wiarygodną wiadomość o takim czynie, musi donieść o nim organom ścigania (Policji, prokuraturze) mimo, że jest związany kanoniczną tajemnicą duszpasterską. W tych przypadkach, ochrona prawna tajemnicy dotycząca faktów pozyskanych w czasie spowiedzi nie ma zastosowania.

\section{Aksjologiczne podstawy och rony tajemnicy duszpasterskiej}

Bez wątpienia z punktu widzenia konstytucyjnych zasad autonomii i niezależności związków wyznaniowych i państwa (art. 25 ust. 3 Konstytucji RP), ze względu na obowiązek poszanowania tych zasad, wypływający także z art. 1 Konkordatu oraz na zasadę swobody w wykonywaniu funkcji religijnych przez Kościół (art. 11 ust. 1

\footnotetext{
${ }^{8}$ Zob. Wyrok Naczelnego Sądu Administracyjnego w Warszawie z dnia 22 czerwca 2010 r. II FSK 364/09 (LEX nr 643580). W sprawie w skardze kasacyjnej skarżący postawił zarzut, iż organy podatkowe wymagały od duchownego informacji, objętych „dyskrecją duszpasterską” rozumianą, jako tajemnica związana z posługą duszpasterską (zbliżoną do tajemnicy zawodowej). Zdaniem tej strony ujawnienie przedmiotwych informacji stanowiłoby naruszenie przepisów prawa kanonicznego, szczególnie kan. 220. Sąd nie uznał, tej argumentacji.
} 
u.g.w.s.w. ${ }^{9}$, w zw. z art. 2 u.s.p.k.k..$^{10}$ ) brak prawnej ochrony (kanonicznej) tajemnicy duszpasterskiej na forum prawa polskiego powinien być uzupełniony. Takie rozwiązanie przysłuży się pełniejszej integralności i większej efektywności ochrony praw związanych z wolnością sumienia i wyznania.

Należy zatem zbadać możliwość wprowadzenia do polskiego systemu prawnego ochrony tejże tajemnicy oraz wskazać problemy, które się z tym mogą wiązać. W rozważaniach zostanie podana argumentacja ujęta z perspektywy doktryny religijnej i prawa największego w Polsce Kościoła katolickiego, czyli Kościoła rzymskokatolickiego. Można jednak zastosowaną argumentację powtórzyć mutatis mutandis, czyli z uwzględnieniem specyfiki doktrynalnej, prawnej oraz duszpasterskiej także i innych związków wyznaniowych działających w Polsce. Należy pamiętać, że przy wprowadzaniu do systemu prawa polskiego regulacji dotyczących kwestii religijnych obowiązuje zasada równouprawnienia kościołów i innych związków wyznaniowych (art. 25 ust. 1 Konstytucji) oraz równości wobec prawa (art. 32 ust 1 Konstytucji).

\section{Relacja państwa i Kościoła}

Konsekwencją niezależności i autonomii Kościoła i państwa Polskiego jest to, że regulacje prawne stanowione przez Kościół czy kanoniczny zwyczaj prawny (będący równorzędnym z prawem stanowionym źródłem w Kościele prawa) nie obowiązują autonomicznie lub automatycznie na forum prawa polskiego. Ich moc prawna uzależniona jest od tego, czy ustawodawca odsyła do nich i tym samym pozwala na włączenie regulacji egzogenicznych oraz określa zakres ich stosowanie w prawie polskim.

Regulacje prawa kanonicznego nie są bowiem zawarte w katalogu powszechnie obowiązującego prawa w Rzeczypospolitej Polskiej

\footnotetext{
${ }^{9}$ Ustawa z dnia 17 maja 1989 r. o gwarancjach wolności sumienia i wyznania (Dz.U. z 2017 r., poz. 1153).

${ }^{10}$ Ustawa z dnia 17 maja 1989 r. o stosunku Państwa do Kościoła Katolickiego w Rzeczypospolitej Polskiej (tekst jedn. Dz. U. z 2013 r. poz. 1169 z późn. zm.).
} 
(zob. art. 87 Konstytucji RP). Jak słusznie zauważył w wyroku z dnia 8 stycznia 2008 r. Naczelny Sąd Administracyjny (II GSK 286/07) „Kodeks Prawa Kanonicznego jest autonomicznym prawodawstwem Kościoła rzymskokatolickiego. Oznacza to, że akt ten nie mieści się w katalogu powszechnie obowiązującego prawa w Rzeczypospolitej Polskiej"l1. To zdanie jest prawdziwe także w przypadku innych niż kodeks aktów normatywnych oraz w przypadku kanonicznego zwyczaju prawnego.

\section{Drogi wprowadzenia ochrony tajemnicy duszpasterskiej}

Na tym tle prima facie jawią się trzy drogi wprowadzenia do polskiego systemu prawnego ochrony (kanonicznej) tajemnicy duszpasterskiej. Pierwsza droga to samodzielne opracowanie stosowanych regulacji przez ustawodawcę. To rozwiązanie jest teoretycznie możliwe do zrealizowania. Nie narusza ono autonomii i niezależności Kościoła, o której była mowa wyżej. Jednakże z tej racji, że od ustawodawcy wymagałoby to wiedzy z zakresu prawa kanonicznego i katolickiej praktyki religijnej, może być ono trudne do poprawnego wykonania. Druga droga to odwołanie się przez ustawodawcę polskiego do przepisów prawa kanonicznego i recypowanie ich na forum prawa polskiego oraz nadanie przedmiotowej tajemnicy ochrony. Wydaje się, że znacznie łatwiej jest przyjąć wypracowane kanoniczne rozwiązania, ewentualnie dokonując w ich przyjmowaniu do polskiego systemu pewnych modyfikacji. Trzecią drogą, która się pojawia i nad którą można się zastanowić, związana jest $\mathrm{z}$ odpowiedzią na pytanie czy zmiana w samych tylko przepisach prawa kanonicznego nie spowoduje zmiany w prawie polskim na mocy już istniejących odwołań prawa polskiego do prawa kanonicznego. To zagadnienie jest obecnie elementem ożywionej dyskusji prowadzonej pomiędzy kanonistami i prawnikami. Skomplikowanie tej kwestii i obfitość argumentów powoduje, że wypada poświęcić jej osobny artykuł ${ }^{12}$.

\footnotetext{
${ }^{11}$ Legalis nr 96023.

${ }^{12}$ Artykuł ukaże się w „Annales Canonici” za rok 2018.
} 


\section{Dyskusja nad drogami wprowadzenia ochrony tajemnicy duszpasterskiej}

Do realizacji pierwszej drogi nie wydaje się konieczna wiedza z zakresu źródła czy celu tajemnicy duszpasterskiej w prawie i nauczaniu doktrynalnym Kościoła oraz zakresu tej tajemnicy czy jej ochrony w prawie kanonicznym. Prawo polskie wyprowadza ratio legis swoich przepisów z własnej aksjologii bez potrzeby posiłkowania się aksjologią kościołów i związków wyznaniowych. Podobnie jak ma to miejsce w przypadku spowiedzi aksjologiczne źródła rozwiązań w prawie polskim byłyby następujące. Po pierwsze, byłaby to przyrodzona godność człowieka (zob. Preambuła i art. 30 Konstytucji RP) - a więc bez konieczności odwołania się do godności nadprzyrodzonej). Po drugie, celem ochrony tajemnicy duszpasterskiej byłaby ochrona praktyk religijnych, których realizacja jest chroniona jako prawo człowieka (art. 53 Konstytucji RP) ${ }^{13}$. Aczkolwiek, wskazana wiedza dotycząca prawa kanonicznego i katolickiej praktyki religijnej może okazać się przydana ustawodawcy w doprecyzowaniu zakresu podmiotowego czy przedmiotowego ochrony tejże tajemnicy.

Z kolei w przypadku drugiej drogi konieczna jest znajomość podstaw doktrynalno-prawnych tajemnicy duszpasterskiej w prawie kanonicznym. Ustawodawca bowiem nie powinien włączać blankietowo, czy bez choćby pobieżnego rozpoznania treści egzogenicznych, norm do polskiego sytemu prawnego. Takie zachowanie bowiem godziłoby w jego powage jako podmiotu kompetentnego merytorycznie do

${ }^{13}$ Zob. np. art. 18 Powszechnej Deklaracja Praw Człowieka z dnia 10 grudnia 1948 r. przyjęta i proklamowana rezolucją Zgromadzenia Ogólnego ONZ 217A/III z dnia 10 grudnia 1948 r., [w:] Wybór dokumentów prawa międzynarodowego dotyczqcych praw człowieka, red. M. Zubik, Warszawa 2008, s. 11-16, czy art. 9 Konwencji o ochronie praw człowieka i podstawowych wolności sporządzona w Rzymie dnia 4 listopada 1950 r. Konwencja o ochronie praw człowieka i podstawowych wolności sporządzona w Rzymie dnia 4 listopada 1950 r. zmieniona następnie Protokołami nr 3, 5 i 8 oraz uzupełniona Protokołem nr 2 (Dz.U. z 1993 r. Nr 61, poz. 284), art. 18 Międzynarodowego paktu praw obywatelskich i politycznych otwarty do podpisu w Nowym Jorku dnia 19 grudnia 1966 r. (Dz.U. z 1977 r. Nr 38, poz. 167). 
stanowienia prawa (co jest elementem założenia o jego racjonalności) i sugerowało brak suwerenności.

\section{Regulacje kanoniczne dotyczące tajemnicy duszpasterskiej}

W związku z powyższym koniecznym staje się przedstawienie choćby skrótowo dyscypliny Kościoła związanej z (kanoniczną) tajemnicą duszpasterską. Kościół wypełniając swoje działania zlecone mu przez Założyciela Kościoła - Jezusa Chrystusa i wynikające z natury Kościoła, za pozwoleniem zainteresowanych wkracza w najbardziej prywatną sferę życia człowieka. Obowiązkiem Kościoła jest uszanowanie prawa korzystającego z posługi duchowej do ochrony intymności. „Tajemnica sakramentalna” (sacramentale sigillum) (kan. $983 \$ 1$, zob. kan. $984 \$ 1$ a także kan. $1388 \$ 1$ ), która obowiązuje duchownego będącego spowiednikiem, nie jest jedyną z form realizacji prawa wiernego do intymności. Także bowiem rozmowa o treściach duchowych katolika lub akatolika $\mathrm{z}$ duchownym również ma być zachowana przez duszpasterza w tajemnicy.

Wprawdzie w prawie kanonicznym brak przepisów regulujących wprost lub całościowo instytucję tajemnicy duszpasterskiej, jednak istnieje wyraźny zakaz dowodowy dotyczący tej tajemnicy. Został on uregulowany w kan. $1548 \$ 2$ pkt 2 . Zgodnie z tym przepisem od obowiązku udzielania odpowiedzi na pytania w sądzie kościelnym są wyjęci „duchowni, w odniesieniu do tego, co im przekazano z racji sprawowania świętej posługi” („clerici, quod attinet ad ea quae ipsis manifestata sunt ratione sacri ministerii") ${ }^{14}$. Zatem chodzi tu o wszystkie czynności wykonywane przez duchownych w ramach

${ }^{14}$ Zob. L. DEL Amo, Kan. 1548, w: Kodeks Prawa Kanonicznego. Komentarz, red. P. Majer, Kraków 2011, s. 1165. Sam fakt ujęcia we wprowadzonym przez autora wyliczeniu w komentarzu osobno przypadku niezdolności do bycia świadkiem osób w odniesieniu do wszystkiego, co poznali przy okazji sakramentalnej spowiedzi $\mathrm{z}$ odwołaniem się do osobnego kan. $1550 \$ 2$ nr 2 oraz przypadku duchownych w odniesieniu do tego, co im przekazano z racji sprawowania świętej posługi, wskazuje na to, że kan. $1548 \$ 2$ n. 1 obejmuje swym zakresem przypadki niechronione przez tajemnicę spowiedzi. 
posługi będącej uczestnictwem w tria munera sacra i mające swoje regulacje w prawie Kościoła lub objęte jego nauczaniem.

Jako aksjologiczną podstawę obowiązywania takiego rozwiązania prawnego można wskazać rację stojącą za kan. $220^{15}$. Przepis ten stanowi o zakazie naruszania dobrego imienia oraz o prawie do ochrony własnej intymności ${ }^{16}$. Zakodowane w kan. 220 dwie normy, czyli norma uznająca, że każdy człowiek ma prawo do zachowania dobrej opinii oraz norma zakazująca nielegalnego naruszania prawa do dobrej opinii, są komplementarnie powiązane ${ }^{17}$. Szczególnie pierwsza z tych norm ma charakter kanonicznej zasady prawnej będącej podstawą w systemie prawa kanonicznego w zakresie ochrony dobrego imienia. Na niej opierają się także inne przepisy np. kanony: $378 \S 1 \mathrm{nr} 2,483 \S 2,1029,1048,1352 \S 2,1361 \S 3,1390 \S 2,1420 \S 4$, $1421 \S 3,1435,1455 \S 3,1483,1548 \S 2 \mathrm{nr} 2,1717 \S 2$, kan. $1741 \mathrm{nr} 3^{18}$. Przedmiotową racją jest konieczność ochrony dobrego imienia, czyli powszechnego szacunku przysługującego osobie na podstawie jej naturalnej godności ${ }^{19}$.

W przypadku (kanonicznej) tajemnicy duszpasterskiej brak kanonicznych bezpośrednio sankcji karnych za jej naruszenie. Także z kan.

\footnotetext{
${ }^{15}$ Szeroko o tym pisze P. SKonieczny, La buona fama: problematiche inerenti alla sua protezione in base al can. 220 del Codice di Diritto Canonico Latino, Romae 2010; zob. nr 2489 i 2492 Katechizmu Kościoła katolickiego, Poznań 1994, w których naucza się, że dobro i bezpieczeństwo drugiego człowieka oraz poszanowanie jego życia prywatnego, a także dobro wspólne są wystarczającymi powodami do wypełnienia obowiązku zachowania dyskrecji wobec prywatnego życia innych ludzi i respektowania ich prawa intymności. W związku z tym każdy człowiek powinien zachować sprawiedliwą dyskrecję wobec prywatnego życia innych ludzi.

${ }^{16}$ J. Krukowski, Komentarz do kan. 220, w: J. Dyduch, W. Góralski, E. Górecki, J. Krukowski, M. Sitarz, Komentarz do Kodeksu Prawa Kanonicznego, Tom II/1. Księga II, Lud Boży, Cz. I, Wierni chrześcijanie, Poznań 2005, s. 38.

${ }^{17}$ J. Krukowski, Prawa wiernych do dobrej opinii i do własnej intymności. Komentarz do kan. 220 KPK z 1983 r., Prawo Kanoniczne 39 (1996) nr 3-4, s. 231.

${ }^{18}$ P. Skonieczny, Pojęcie dobrego imienia (bona fama) w Kodeksie Prawa Kanonicznego z 1983 r. Jana Pawła II na podstawie kan. 220, Prawo Kanoniczne 59 (2009), nr 1-2, s. 61.

19 Tamże, s. 60.
} 
220 nie wynika wprost żadna sankcja za jego naruszenie. Jednakże możliwe jest zbudowanie pełnej normy prawnej w oparciu o inne przepisy kodeksu i ukaranie wyjawiającego tajemnicę duszpasterską sprawiedliwą karą (zob. kan. 1399).

Jeżeli chodzi o inne konsekwencje niezachowania (kanonicznej) tajemnicy duszpasterskiej to zeznania, które zostałyby złożone w wyniku jej niezachowania, teoretycznie mogłyby stanowić materiał dowodowy ${ }^{20}$, chyba że zostałyby uznane przez sędziego jako zdobyte w sposób niegodziwy (kan. $1527 \$ 1$ oraz art. 157 Instrukcji Dignitas connubii $\left.{ }^{21}\right)$.

\section{Zakres podmiotowy i przedmiotowy ochrony tajemnicy duszpasterskiej}

Zarówno przy realizacji drogi pierwszej (stanowienie), jak i drugiej (recypowanie) proponowany zakres „tajemnicy duszpasterskiej” i jej ochrony należy rozważyć w zakresie podmiotowym i przedmiotowym, który miałby być przyjęty w prawie polskim.

Gdy chodzi o zakres przedmiotowy, to objęte byłyby nim wszelkie informacje udzielone przez osobę (niekoniecznie należącą do Kościoła katolickiego), które nie podlegają „tajemnicy sakramentalnej”, czyli w polskim języku prawniczym „tajemnicy spowiedzi”, a zostały przekazane duchownemu podczas lub w związku ze sprawowaniem przez duchownego jego duszpasterskiej posługi.

Podobnie jak przy regulacjach prawa polskiego dotyczących ochrony tajemnicy spowiedzi nie ma potrzeby definiowania ustawowo terminu „duchowny”. Sąd Najwyższego w uchwale 7 sędziów z dnia 16 maja 1992 r., sygn. I KZP1/91, OSNK 1992, nr 7-8, poz. 46 w odniesieniu do kodeksu postępowania karnego stwierdził, że duchownym

\footnotetext{
${ }^{20}$ Zob. R. Sztychmiler, Komentarz do kan. 1548, w: G. Erlebach, A. Dzięga, J. Krukowski, R. Sztychmiler, Komentarz do Kodeksu Prawa Kanonicznego, Tom V. Księga VII, Procesy, Poznań 2007, s. 202.

${ }^{21}$ Pontificium Concilium de Legum Textibus, Instructio servanda a tribunalibus dioecesanis et interdioecesanis in pertractandis causis nullitatis matrimonii Dignitas connubii (25.01.2005), Città del Vaticano 2005; tekst polski w: Kodeks Prawa Kanonicznego. Komentarz, red. P. Majer, Kraków 2011, s. 1497-1596.
} 
jest „osoba należąca do Kościoła katolickiego lub innego Kościoła albo związku wyznaniowego, która wyróżnia się spośród ogółu wyznawców danej religii tym, że powołana została do stałego organizowania i sprawowania kultu religijnego". To wyróżnienie odbywa się już zgodnie z prawem danego związku wyznaniowego. W przypadku Kościoła chodzi o mężczyzn, który przyjęli święcenia przynajmniej na stopniu diakonatu (kan. $266 \$ 1$, kan. 1024). Do zakresu przedmiotowego nie zaliczałyby się także wszystkie rozmowy osób $\mathrm{z}$ duchownymi, a jedynie te, które odbywałaby osoba $z$ duchowym $z$ racji jego specyficznej pozycji w Kościele i ze względu na sprawowane przez niego funkcje, a nie w sytuacji, w której duchowny występowałby jako zwykły podmiot obrotu gospodarczego (np. zawarcie umowy sprzedaży) czy uczestnik życia społecznego.

Problemem pozostaje, czy sam fakt rozmowy duszpasterskiej również byłby objęty tajemnicą. Wydaje się, że nie. Samo zainicjowanie rozmowy z reguły toczy się publicznie (np. przyjście do kancelarii parafialnej w godzinach jej urzędowania). Wyłącznie sama rozmowa toczyć się będzie z zachowaniem technicznych warunków gwarantujących dyskrecję $e^{22}$. Także objęcie tajemnicą nie może powodować zakazu tworzenia kopii audiowizualnych lub sporządzania dokumentu $\mathrm{z}$ samego faktu odbycia lub przeprowadzenia rozmowy ${ }^{23}$. Takie czyny są notabene penalizowane i objęte surową sankcją (np. ekskomuniką latae sententiae, wydaleniem lub pozbawieniem urzędu, jeśli jest duchownym) na gruncie prawa kanonicznego w stosunku do sakramentu spowied $\mathrm{zi}^{24}$.

\footnotetext{
${ }^{22}$ Stąd też za błędne należy uznać zdanie - „Przez zachowanie tajemnicy należy rozumieć nieujawnianie bezpośrednio lub pośrednio żadnej osobie faktu odbycia się (...) rozmowy duszpasterskiej”, M. Huca£ \$105 PS, w: Prawo Kościoła Ewangelicko-Augsburskiego. Komentarz, red. J. Cebula, Warszawa 2007, Legalis.

${ }^{23}$ A tak chce np. M. Huca£ $\$ 105$ PS, w: Prawo Kościoła Ewangelicko-Augsburskiego. Komentarz, red. J. Cebula, Warszawa 2007, Legalis.

${ }^{24}$ Congregatio pro Doctrina Fidei, Decretum de sacramenti Paenitentiae dignitate tuenda, 23.09.1988, AAS 80 (1988), s. 1367. Zgodnie z art. $4 \$ 2$ dokumentu Normae de delictis Congregationi pro Doctrina Fidei reservatis seu Normae de delictis contra fidem necnon de gravioribus delictis, 21.05.2010, AAS 102 (2010),
} 
Odnośnie zakresu podmiotowego tajemnicy duszpasterskiej, do zachowania tajemnicy zobowiązani byliby - jak to jest analogicznie w prawie kanonicznym - wyłącznie duchowni. Tylko o takich osobach stanowi kan. $1548 \$ 2$ pkt 2 kodeksu prawa kanonicznego. Wprawdzie zdarza się, że duchowych porad udzielają także osoby świeckie (zob. kan. $207 \$ 1$ ), a wśród nich osoby konsekrowane niebędące duchownymi, czyli bracia zakonni czy siostry zakonne (kan. $207 \$ 2$ ). Jednak z racji niewielkich ram tego zjawiska i pomijania go przez prawo kanoniczne, w prawie polskim należałoby zachować taki sam zakres. Nie widać potrzeby jego zwiększania.

Nie byłoby także konieczne przy regulacji (kanonicznej) tajemnicy duszpasterskiej w prawie polskim włączanie w zakres podmiotowy przepisu tłumaczy i innych osób (postronnych), które w jakikolwiek sposób nabyły wiadomości z duszpasterskiej rozmowy. Wprawdzie prawo kanoniczne zobowiązuje te osoby do tajemnicy [spowiedzi] (secretum) (kan. $983 \$ 2$, a także kan. $1388 \$ 2$ ), jednakże rozszerzenie katalogu objętych ochroną poza duchownych prowadziłoby do trudności w dowodzeniu w postępowaniu prowadzonym na gruncie prawa polskiego. Trzeba zauważyć, że korzystanie z kierownictwa duchowego nie ma takiej samej wagi dla duchowego życia osoby, jak sakramentalna spowiedź z uwagi na skutki tej drugiej, jakimi są zgodnie z wiarą katolicką - odpuszczenie grzechów i uzyskanie zbawienia. Można więc zakładać, że osoba chcąca skorzystać z rozmowy duszpasterskiej nie musi jej odbywać w niesprzyjających warunkach, czyli z duchownym, z którym nie potrafi się samodzielnie porozumieć lub w okolicznościach, które nie gwarantują pełnej dyskrecji.

s. 419-431 to Kongregacja Nauki Wiary osądza również najcięższe przestępstwo, polegające na nagrywaniu za pomocą jakichkolwiek urządzeń technicznych albo na rozpowszechnianiu w złych zamiarach w środkach społecznego przekazu tego, co zostało powiedziane przez spowiednika lub penitenta w spowiedzi sakramentalnej, prawdziwej lub fałszywej. 


\section{Zakaz dowodowy w prawie polskim}

Odnosząc się do charakteru zakazu ujawniania (kanonicznej) tajemnicy duszpasterskiej, należałoby wskazać, że norma chroniąca tajemnicę duszpasterską przyjąć powinna w procedurach karnej, cywilnej i administracyjnej charakter zakazu dowodowego. Dlatego też pytania, na które należałoby odpowiedzieć, brzmią następująco:

1. Czy taki zakaz dowodowy miałby mieć charakter zupełny czy niezupełny ${ }^{25}$ ?

2. Czy byłby on bezwzględny (bezwarunkowy) czy też względny (warunkowy) ${ }^{26}$ ?

3. Czy omawiany zakaz dowodowy miałby być brany pod uwagę przez organ orzekający z urzędu (jak w przypadku np. tajemnicy obrończej unormowanej w art. 178 pkt 1 k.p.k.), czy też może wprowadzono by go w formie prawa do odmowy odpowiedzi na pytania zadane $\mathrm{w}$ trakcie przesłuchania (jak to jest w przypadku tajemnicy spowiedzi w art. $261 \$ 2$ k.p.c.)? ad 1. Odnosząc się kolejno do przedstawionych kwestii, podział na zakaz dowodowy zupełny i niezupełny dotyczy możliwości dowodzenia określonych faktów w ogóle ${ }^{27}$. Przykładem pierwszego jest zakaz dowodzenia przebiegu narady sędziowskiej. Jest ona tajna i nigdy nie można odtwarzać jej przebiegu za pomocą żadnego dowodu (art. $108 \$ 1$ k.p.k., por. kan. $1455 \$ 2$ ). Z oczywistych względów przepis chroniący tajemnicę duszpasterską nie mógłby wprowadzać zakazu zupełnego. Fakt bowiem przekazany podczas rozmowy z duszpasterzem, dotyczący popełnienia jakiegoś przestępstwa czy też samej obecności osoby w danym miejscu o określonej porze, mógłby być dowodzony innym środkiem dowodowym, np. nagraniem lub

\footnotetext{
${ }^{25}$ Podział na dowody zupełne i niezupełne za M. Cieślak, Zagadnienia dowodowe $w$ procesie karnym, Warszawa 1955, s. 265 i n.

${ }^{26}$ Podział na dowody bezwzględne (bezwarunkowe) i względne (warunkowe) zob. S. Waltoś, P. Hofmański, Proces karny. Zarys systemu, Warszawa 2016, s. 366 i n. oraz T. Grzegorczy k, J. Tylman, Polskie postępowanie karne, Warszawa 2015, s. $457 \mathrm{i} \mathrm{n}$.

${ }^{27}$ M. Cieślak, Zagadnienia dowodowe w procesie karnym, Warszawa 1955, s. 265-268.
} 
zeznaniem świadka. Klasyfikacja zatem proponowanego zakazu dowodowego dotyczącego tajemnicy duszpasterskiej w tym zakresie jest rzeczą prostą. Inaczej jest odnośnie kolejnego podziału.

ad 2. Wyróżnienie zakazów bezwzględnych (bezwarunkowych) i względnych (warunkowych) dotyczy możliwości ich uchylenia $\mathrm{w}$ trakcie prowadzonego postępowania ${ }^{28}$. W stosunku do pierwszego z rodzajów zakazów nie przewiduje się możliwości uchylenia. Przykładem jest regulacja dotycząca tajemnicy spowiedzi i tajemnicy obrończej w postępowaniu karnym (art. 178 k.p.k.). Z kolei zakaz dowodowy względny przewiduje możliwość jego uchylenia pod określonymi w prawie warunkami. Przykładem są przepisy chroniące tajemnicę zawodową (np. notarialną ${ }^{29}$, adwokacką ${ }^{30}$, radcy prawnego ${ }^{31}$, doradcy podatkowego ${ }^{32}$, lekarską ${ }^{33}$, dziennikarską ${ }^{34}$, statystyczną ${ }^{35}$ czy tajemnicę Prokuratorii Generalnej ${ }^{36}$ ) w polskiej procedurze karnej. Zgodnie z tymi przepisami osoby zobowiązane do zachowania tajemnicy moga być przesłuchiwane co do faktów nią objętych tylko wtedy, gdy jest to niezbędne dla dobra wymiaru sprawiedliwości, a okoliczność nie

${ }^{28}$ S. Waltoś, P. Hofmański, Proces karny. Zarys systemu, Warszawa 2016, s. $366-375$.

${ }^{29}$ Art. 18 ustawy z dnia 14 lutego 1991 r. Prawo o notariacie (tekst jedn. Dz. U. z 2016 r. poz. 1796 z późn. zm.).

${ }^{30}$ Art. 6 ustawy z dnia 26 maja 1982 r. Prawo o adwokaturze (tekst jedn. Dz. U. z 2016 r. poz. 1999 z późn. zm.).

${ }^{31}$ Art. 3 ustawy z dnia 6 lipca 1982 r. o radcach prawnych (tekst jedn. Dz. U. z 2016 r. poz. $233 \mathrm{z}$ późn. zm.).

${ }^{32}$ Art. 37 ustawy z dnia 5 lipca 1996 r. o doradztwie podatkowym (tekst jedn. Dz. U. z 2016 r. poz. 794 z późn. zm.).

${ }^{33}$ Art. 40 ustawy z dnia 5 grudnia 1996 r. o zawodach lekarza i lekarza dentysty (tekst jedn. Dz. U. z 2017 r. poz. 125 z późn. zm.)

${ }^{34}$ Art. 15 ustawy z dnia 26 stycznia 1984 r. Prawo prasowe (Dz. U. Nr 5, poz. 24 z późn. zm.).

${ }^{35}$ Art. 10 ustawy z dnia 29 czerwca 1995 r. o statystyce publiczne (tekst jedn. Dz. U. z 2016 r. poz. 1068).

${ }^{36}$ Art. 38 i 39 ustawy z dnia 15 grudnia 2016 r. o Prokuratorii Generalnej Rzeczypospolitej Polskiej (Dz. U. z 2016 r., poz. 2261). 
może być ustalona na podstawie innego dowodu (art. $180 \$ 2$ oraz art. 225 i 226 k.p.k.).

Decyzja, czy (kanoniczną) tajemnicę duszpasterską chronioną w prawie polskim można byłoby uchylić i w jaki sposób to można byłoby uczynić, wymaga kilku decyzji. Po pierwsze, trzeba określić wagę (kanonicznej) tajemnicy duszpasterskiej. Po drugie, w przypadku zdefiniowania (kanonicznej) tajemnicy duszpasterskiej jako objętej zakazem dowodowym względnym, wskazania organu, który byłby władny z zachowania tej tajemnicy zwolnić.

Pewne jest, że tajemnica duszpasterska ma duże znaczenie zarówno dla duchownych jak i osób korzystających z ich posługi. Już samo nazwanie ją w doktrynie prawa kanonicznego i w literaturze prawniczej „tajemnicą” daje pewną wskazówkę co do jej rangi. Wydaje się, że dla zainteresowanych, tj. duszpasterzy obowiązanych do jej zachowania na podstawie prawa kanonicznego oraz osób korzystających $\mathrm{z}$ ich posługi, najkorzystniejsze byłoby objęcie tej tajemnicy zakazem dowodowym bezwzględnym. Taki sposób uregulowania pozwoliłby także uniknąć konieczności podejmowania decyzji, dotyczących podmiotu władnego do uchylenia tego zakazu dowodowego. Nie wydaje się jednak, aby należałoby tę tajemnicę sklasyfikować w prawie polskim na równi z tajemnicą spowiedzi - skoro nawet prawo kanoniczne takiego znaku równości pomiędzy tajemnicami nie stawia. Oznacza to, że właściwsze byłoby objęcie (kanonicznej) tajemnicy spowiedzi zakazem dowodowym względnym.

Przy przyjęciu tego stanowiska należy określić organ, który byłby władny zwolnić duszpasterza z obowiązku zachowania tej tajemnicy na forum prawa polskiego. Należy zauważyć, że skoro Kościół cieszy się niezależnym i autonomicznym zarządzaniem w swoich sprawach, to wydaje się, że wskazane byłoby, gdyby jednostką władną zwolnić z obowiązku zachowania tajemnicy duszpasterskiej byłby organ funkcjonujący na podstawie prawa kanonicznego. Jednak to rozwiązanie ma poważne wady. Po pierwsze, prawo kanoniczne nie przewiduje możliwości zwolnienia z (kanonicznej) tajemnicy duszpasterskiej na forum prawa kanonicznego. Organ działający w oparciu o prawo kanoniczne (specjalnie do tego utworzony lub któremu 
prawo kanoniczne przyznałoby takie kompetencje - mógłby być to sąd diecezjalny) musiałby zwalniać jedynie z tajemnicy na forum prawa polskiego. Po drugie, takie rozwiązanie byłoby niepraktyczne dla organów wymiaru sprawiedliwości, gdy chodzi o cele ich działania (zob. np. art. $2 \$ 1$ k.p.k.), a szczególnie efektywność postępowania wyrażającą się w rozsądnym terminie jego zakończenia. Odwołanie się do organu prawa kanonicznego i czas oczekiwania na jego decyzję powodowałby przedłużanie spraw na gruncie prawa polskiego.

W obliczu tych argumentów wydaje się, że ustawodawca polski uznałby za bardziej praktyczne, aby to organ działający na podstawie prawa polskiego zwalniał duchownego z przedmiotowej tajemnicy. To rozwiązanie, jak się wydaje, nie naruszałoby konkordatowych i ustawowych gwarancji swobodnego wykonywania przez Kościół władzy duchowej czy jurysdykcyjnej (art. 1 Konkordatu; art. 2 u.s.p.k.k). Po zwolnieniu bowiem $\mathrm{z}$ tajemnicy na forum prawa polskiego, tajemnica na forum prawa kanonicznego obowiązywałaby nadal. Aczkolwiek z uwagi na zasadę jawności rozpraw, w myśl której społeczeństwo ma dostęp do wiadomości ujawnionych w jej trakcie (art. 45 ust. 1 Konstytucji oraz np. art. 355 k.p.k., art. 9 i 148 k.p.c. oraz art. 10 i 90 p.p.s.a. ${ }^{37}$ ) tajemnica na forum prawa kanonicznego może utracić praktyczne znaczenie ${ }^{38}$, o ile nie zastosowano instytucji wyłączenia jawności dozwolonej przez Konstytucję w art. 45 ust. 2 z uwagi na ochronę życia prywatnego stron i inny ważny interes prywatny ${ }^{39}$.

${ }^{37}$ Ustawa z dnia 30 sierpnia 2002 r. Prawo o postępowaniu przed sądami administracyjnymi (tekst jedn. Dz. U. z 2017 r. poz. 1369 z późn. zm.) - dalej jako p.p.s.a..

${ }^{38}$ S. Waltoś, P. Hofmański, Proces karny. Zarys systemu, Warszawa 2016, s. 316.

${ }^{39}$ Zgodnie $\mathrm{z}$ art. $360 \$ 1$ pkt 1 lit. d k.p.k. sąd może wyłączyć jawność rozprawy w całości albo w części, jeżeli jawność mogłaby naruszyć ważny interes prywatny. Zgodnie z art. $153 \$ 2$ k.p.c. sąd może zarządzić odbycie posiedzenia lub jego części przy drzwiach zamkniętych na wniosek strony, jeżeli m.in. podane przez nią przyczyny uzna za uzasadnione lub jeżeli roztrząsane być mają szczegóły życia rodzinnego. Postępowanie dotyczące tego wniosku odbywa się przy drzwiach zamkniętych. Zgodnie $z$ art. $96 \$ 2$ p.p.s.a. sąd na wniosek strony zarządza odbycie posiedzenia przy drzwiach zamkniętych, jeżeli wymaga tego ochrona życia prywatnego strony lub inny ważny interes prywatny. 
Możliwe bowiem byłoby, z uwagi na uchylenie tajemnicy duszpasterskiej i konieczność złożenia zeznań odnośnie faktów z najbardziej intymnej sfery życia człowieka (o czym była mowa powyżej), co mogłoby wyrządzić krzywdę określonemu uczestnikowi procesu, wydanie postanowienia przez sąd o wyłączeniu jawności (w procedurze karnej) lub o odbyciu posiedzenia lub jego części przy drzwiach zamkniętych (procedura cywilna i sądowoadministracyjna ${ }^{40}$ ). Wówczas m.in. udział osób na rozprawie jest ograniczony. Ogłoszenie wyroku zawsze jednak będzie odbywać się jawnie (art. 45 ust. 2 Konstytucji RP, art. 364 k.p.k., $154 \$ 2$ k.p.c. i art. $139 \$ 2$ p.p.s.a.).

ad 3. Odnośnie rozstrzygnięcia kwestii tego, czy należy brać pod uwagę omawiany zakaz dowodowy z urzędu czy uzależnić korzystanie z niego od decyzji duchownego (poprzez prawo odmowy odpowiedzi na pytanie) trzeba powiedzieć, że przy zakazie dowodowym niezupełnym i względnym bardziej właściwa byłaby ta druga forma. Wówczas zakaz dowodowy zaczynałby obowiązywać dopiero w momencie, gdy uprawniony składałby oświadczenie z chęci skorzystania z przysługującego mu prawa. To sam duchowny musiałby dbać o to, by w odpowiednim momencie w trakcie przesłuchania skorzystać z możliwości odmowy na pytanie dotyczące faktów objętych (kanoniczną) tajemnicą duszpasterską. W przypadku braku oświadczenia o skorzystaniu z prawa do odmowy odpowiedzi na pytanie zeznania duchownego, pod warunkiem niezachodzenia innych okoliczności dyskredytujących, byłyby pełnoprawnym dowodem w sprawie. Jeżeli jednak przepis miałby formę zakazu dowodowego bezwzględnego, wówczas nic nie stałoby na przeszkodzie nakazaniu brania

\footnotetext{
${ }^{40}$ Odnośnie postępowania sądowoadministracyjnego należy zwrócić uwagę, iż sąd administracyjny bada jedynie prawidłowość postępowania prowadzonego przez organ administracyjny, biorąc pod uwagę zebrane już w aktach materiały. Mozliwość dopuszczenia dowodu w postępowaniu przed sądem administracyjnym tyczy się rzadkich przypadków i tylko dowodów z dokumentu. Sąd administracyjny - co do zasady - nie przesłuchuje świadków. Procedura administracyjna nie przewiduje możliwości utajnienia protokołu z przesłuchania świadka z powodów, jakie przewidują trzy procedury sądowe, chociaż sam jej charakter powoduje, że swobodny wgląd do akt mają teoretycznie tylko strony postępowania.
} 
pod uwagę ograniczeń dowodowych w tym zakresie z urzędu przez organ orzekający.

\section{Kwestie redakcyjno-legislacyjne}

Gdy chodzi o kwestie redakcyjno-legislacyjne (kanoniczna) tajemnica duszpasterska mogłaby być wprowadzona i chroniona w przepisach prawa polskiego regulujących wymienione już wyżej procedury.

$\mathrm{W}$ procedurze karnej w przypadku wprowadzenia zakazu warunkowego możliwe byłoby dodanie tajemnicy duszpasterskiej do art. $180 \$ 2$ k.p.k. w przykładowy sposób: „Osoby obowiązane do zachowania tajemnicy notarialnej, adwokackiej, radcy prawnego, doradcy podatkowego, lekarskiej, dziennikarskiej, tajemnicy duszpasterskiej lub statystycznej oraz tajemnicy Prokuratorii Generalnej mogą być przesłuchiwane co do faktów objętych tą tajemnicą tylko wtedy, gdy jest to niezbędne dla dobra wymiaru sprawiedliwości, a okoliczność nie może być ustalona na podstawie innego dowodu. $\mathrm{W}$ postępowaniu przygotowawczym w przedmiocie przesłuchania lub zezwolenia na przesłuchanie decyduje sąd, na posiedzeniu bez udziału stron, w terminie nie dłuższym niż 7 dni od daty doręczenia wniosku prokuratora. Na postanowienie sądu przysługuje zażalenie".

W przypadku wprowadzenia zakazu bezwzględnego tajemnica duszpasterska mogłaby być dodana do art. 178 k.p.k. ${ }^{41}$.

Procedura cywilna mogłaby ulec zmianie w art. $161 \$ 2$ k.p.c. „Świadek może odmówić odpowiedzi na zadane mu pytanie, jeżeli zeznanie mogłoby narazić jego lub jego bliskich, wymienionych w paragrafie poprzedzającym, na odpowiedzialność karną, hańbę lub dotkliwą i bezpośrednią szkodę majątkową albo jeżeli zeznanie miałoby być połączone z pogwałceniem istotnej tajemnicy zawodowej. Duchowny może odmówić zeznań co do faktów powierzonych mu na spowiedzi albo objętych tajemnicą duszpasterską".

W procedurze administracyjnej modyfikacji uległby art. 82 k.p.a. „Świadkami nie mogą być: 1) osoby niezdolne do spostrzegania lub

\footnotetext{
${ }^{41}$ Tak bardzo trafnie proponuje M. Tomkiewicz, "Tajemnica spowiedzi" i "tajemnica duszpasterska" w procesie karnym, Prokuratura i Prawo (2012) nr 2, s. 65.
} 
komunikowania swych spostrzeżeń; 2) osoby obowiązane do zachowania w tajemnicy informacji niejawnych na okoliczności objęte tajemnicą, jeżeli nie zostały w trybie określonym obowiązującymi przepisami zwolnione od obowiązku zachowania tej tajemnicy; 3) duchowni co do faktów objętych tajemnicą spowiedzi albo tajemnicą duszpasterską".

W trakcie postępowania sądowoadministracyjnego sąd administracyjny co do zasady nie przeprowadza postępowania dowodowego. Wyjątkowo sąd może $z$ urzędu lub na wniosek stron przeprowadzić dowody uzupełniające, jeżeli jest to niezbędne do wyjaśnienia istotnych wątpliwości i nie spowoduje nadmiernego przedłużenia postępowania w sprawie. Mają to być tylko i wyłącznie dowody z dokumentów (art. $106 \$ 3$ p.p.s.a.). Dlatego w zakresie tej procedury wprowadzanie nowych zakazów dowodowych jest zbędne.

Możliwe byłoby także, obok proponowanych wyżej zmian przepisów, wprowadzenie do ustawy o gwarancjach wolności sumienia i wyznania artykułów o brzmieniu: „Nie wolno przesłuchiwać jako świadka duchownego co do faktów objętych tajemnicą duszpasterską" oraz „Zakres tajemnicy duszpasterskiej oraz osoby zobowiązane do jej zachowania podlega ocenie zgodnie z prawem wewnętrznym kościoła albo innego związku wyznaniowego", co dodatkowo wzmocniłoby pozycję tajemnicy duszpasterskiej w prawie polskim.

\section{Korzyści z ochrony tajemnicy duszpasterskiej}

Wprowadzenie ochrony (kanonicznej) tajemnicy duszpasterskiej do polskiego systemu prawnego jest zabiegiem pożądanym. Chodzi o zabezpieczenie podstawowych praw człowieka, jakim jest prawo do wolności religijnej. Elementem tego zabezpieczenia jest zagwarantowanie swobody wykonywania praktyk religijnych poprzez zapewnienie poufności treści rozmów duszpasterskich. Rozmowy te, ponieważ są prowadzone $z$ duchownymi w ramach i z racji ich pozycji i zadań, które wykonują w związkach wyznaniowych, należą do intymnej sfery życia i powodują szczególny stosunek pomiędzy interlokutorami. Prawo polskie tę relację powinno chronić. 
Wprowadzenie przedmiotowej ochrony byłoby nie tylko korzystne dla duchownych Kościoła rzymskokatolickiego lub osób korzystających z ich posługi, ale także dla innych kościołów lub związków wyznaniowych posiadających własną ustawę o stosunku z Rzeczpospolitą Polską, względnie związków wyznaniowych zarejestrowanych w Polsce. Istnieje jednak warunek obowiązywalności regulacji polskich w stosunku tych związków wyznaniowych. Z tej racji, że w przyjęciu drugiej drogi, czyli recepcji prawa kościoła lub innego związku religijnego przez prawo polskie, takie religijne zrzeszenie musi posiadać w swoim prawie lub doktrynie religijnej „tajemnicę duszpasterską", którą nakazuje zachować duchownym. Trzeba bowiem koniecznie zwrócić uwagę na to, że w propozycji podanej powyżej ustawodawca polski nie „stwarza” tajemnicy duszpasterskiej i nadaje jej ochronę w polskim porządku prawnym (to by miało miejsce w przypadku obrania pierwszej drogi), lecz przyjmuje ją z obcego (religijnego) systemu prawnego jedynie modyfikując jej zakres przedmiotowy i podmiotowy.

Notabene identyczne rozwiązanie przyjęto w procedurze administracyjnej, gdzie wprost chodzi o fakty objęte już tajemnicą spowiedzi na forum prawa związku wyznaniowego. Model z kodeksu postępowania administracyjnego należałoby powielić $\mathrm{w}$ przypadku stanowienia o tajemnicy duszpasterskiej. Z kolei w przepisach regulujących procedurę karną i cywilną, stanowi się o ochronie faktów, o których duchowny „dowiedział się przy spowiedzi” (k.p.k.) i faktach „powierzonych mu na spowiedzi” (k.p.c.). Ta ochrona istnieje na forum prawa polskiego niezależnie od jej ochrony w prawie religijnym.

\section{Several remarks on the protection of (canonical) pastoral secrecy in Polish law}

Both, Polish law and canon law contain regulations prohibiting the disclosure of certain information. These regulations concern own affairs in the internal forum of the state or the Church, and also the foreign affairs. Polish law protects the sacramental seal of confession, for example, but it lacks protection for the (canon) pastoral secrecy. Introducing the protection 
of this secret into the Polish legal system is a desirable aim that would safeguard fundamental human rights, which is the right to religious freedom, by ensuring that the contents of pastoral talks are kept confidential. This article discusses the possibility of introducing the protection of this secret to the Polish legal system through the reception of canonical regulations and indicates problems that may be associated with it.

SŁOWA KLUCZOWE: kan. 220; tajemnica spowiedzi; tajemnica duszpasterska; recepcja prawa

KEYWORDS: can. 220; sacramental seal; pastoral secrecy; reception of the law

\section{Nota o Autorach:}

Makgorzata Chojara-Sobiecka - radca prawny

Ks. Dr hab. Piotr Kroczek, prof. UPJPII - pracownik naukowo-dydaktyczny na Wydziale Nauk Społecznych Uniwersytetu Papieskiego Jana Pawła II w Krakowie, kierownik Katedry prawa rodzinnego, autor licznych prac z zakresu kanonicznego prawa małżeńskiego i wyznaniowego, Kościelny Inspektor Ochrony Danych. 